\title{
BIOMASS ASH UTILIZATION OPPORTUNITIES IN AGRICULTURE
}

Oskars KARPS, Latvia University of Agriculture, Faculty of Engineering, Institute of Agricultural machinery, Cakstes blvd.5, Jelgava, LV-3001, Latvia, oskars.karps@inbox.lv

Aivars ABOLTINS, Latvia University of Agriculture, Faculty of Engineering, Institute of Agricultural Machinery, Cakstes blvd.5, Jelgava, LV-3001, Latvia, aivars.aboltins@1lu.lv

Janis PALABINSKIS, Latvia University of Agriculture, Faculty of Engineering, Institute of Agricultural machinery, Cakstes blvd.5, Jelgava, LV-3001, Latvia, janis.palabinskis@ @lu.lv (corresponding author)

In Latvia and in the world there are problems with utilization of wood ash from large fireboxes because it is a technologically complicated, time consuming and costly process. The methods used to dispose of the ash when it is deposited in waste landfills are unsustainable. Pollution-increasing solution is needed since pure wood ash is a valuable source of plant nutrients. Ash contains the macro and microelements needed for plants and can replace some of the precious mineral fertilizers in agriculture, especially in organic. Ash use in agriculture is little explored and implemented, the use of the technology is not resolved (ash collection and screening, fractionation, drilling, evaluation, etc.). The LUA studies of ash and slurry mixing problem to prepare ash with mechanized spreaders. Cattle slurry is used as a binder that helps create solid ash fractions that are subject to dispersion with centrifugal fertilizer dispersers with a sufficiently good spreading quality. The research examines the conditions for the creation of different size fractions and their dissolution. The experimental results showed that the best used ratio of the mixtures was $1000 \mathrm{ml}$ of ash and 200 ml of liquid manure or $1000 \mathrm{ml}$ of ash and $300 \mathrm{ml}$ of liquid manure. In this ratio, the produced granule size was very close to the size of mineral fertilizers.

Keywords: mixing, slurry, wood ash, granulation

\section{INTRODUCTION}

Biomasses are organic materials that are derived from any living or recently-living structure. Plenty of biomasses are produced in the world. Biomasses are mostly combusted for heat and electricity produsing. Use of wood-based biomass for energy has been a major socio-economic function of forests all over the world. The potential negative impact on the forest ecosystem and surrounding environment due to an increased utilization of wood-based biomass for energy needs to be mitigated. Possibilities of using ashes in various branches of economy have been widely studied worldwide in recent years.

Wood ash is a residue powder that is left after combustion of wood in home or in industries. Typically 6-10\% of the mass of burnt wood result in ash (Siddique, 2012). The type of wood, combustion temperature and combustion time play a vital role in the quantity of ash produced and its chemical composition. Renewable energy sources accounted for a $36.8 \%$ (approx. $69 \mathrm{PJ}$ ) share of the gross inland energy consumption in Latvia, 2014 (Central Statistical Bureau,2015). $82.1 \%$ of renewable energy was produced by different kinds of wood fuel, but $24.3 \%$ of it was produced in cogeneration plants (Central Statistical Bureau,2015). Energy wood is gradually becoming more and more important in the energy supply of Latvia. This is due to the European Union's decisions to increase the share of renewable energy in order to reach $20 \%$ of the share of renewable energy in total energy consumption in 2020.

Biomass heating systems are becoming increasingly popular because of the use of cheap local fuels, and thus promoting national energy independence. However, the use of such equipment results in the production of ash, which in Latvia, like many other parts of the world, is treated as industrial waste. As such, it is mostly deposited at landfills. For example, in 2012, more than 33 thousand tons of wood ash was produced in Latvia (Bekeris, 2015). Much of this ash is today considered as waste and is deposited on landfills at a considerable cost. Wood ash contains all the major mineral plant nutriens except nitrogen and has a liming effect when returned to the soil.

Environmental policies of the European Union aim to increase the amount of renewable energy and to improve the use of waste streams. This will increase the amount of ash from biomass combustion, thereby increasing the need for its utilization. Dumping high quality wood ash in landfill conflicts with public efforts to reduce the flow of waste to landfill. In recent years, attention has been focused on the use of ashes. As one of the options is wood ash recycling that returns the nutrients in the trees to their place of origin, i.e. forest soil. The ecological effects of ash recycling on flora, fauna and tree growth and on water and soil chemistry have been thoroughly studied in recent decades. These studies show that pure, noncontaminated and stabilised wood ash can be used as a compensatory fertiliser on forest soils without any significant negative

Copyright (C) 2017 The Authors. Published by Aleksandras Stulginskis University. This is an open-access article distributed under the terms of the Creative Commons Attribution License (CC-BY 4.0), which permits unrestricted use, distribution, and reproduction in any medium, provided the original author and source are credited. 
impact on the environment, provided that the ash is applied with consideration to site specific conditions. The influence of wood ash on the soil chemical composition and biochemical parameters of young Scots pine was studied (Mandre, 2006).

The effect of fertilization with ashes on the above-and belowground biomass formation of Silver birch and Scots pine stands on peatland was investigated (Ots, 2017). Other wood ash mode of application is its use in forest road construction and maintenance. Ash from woody biomass contains a significant amount of $\mathrm{CaO}$. Therefore, the substitution of burnt lime as a binder for silt and clay soil stabilisation by wood ash seems to be a reasonable way of ash utilization (Thurdin and etc. 2006, Oburger and etc, 2016).

With the advancement of the technology and increased field of applications of concrete and mortars it is possible to make it more suitable for by situations. The percentage of $\mathrm{CaO}$, which is one of the important compounds in wood ash, varies from $4 \%$ to $70 \%$ in wood ash that makes it a potential substitute in cement industry either in the production or in the application stage. An investigation was performed with a view to establish various physical properties of wood ashes and to determine potential uses of wood ashes in cement-based construction materials (Siddique, 2012, Garsia and SausaCoutinho, 2013, Carrasco and etc 2014, Kizinievic 2016, Fernández-Pereira 2011).

Biomass ash adopted as the additive to increase freeammonia concentration in biogas slurry was investigated (Shuiping Y and etc. 2017), the effects of biomass ash on the composting process of separated organic fraction of municipal waste and the final product quality were studied (Asquer and etc.2017).

Wood Ash contains significant amounts of magnesium, potassium and many other micronutrients important to healthy crop growth. Wood ash has been chosen by farmers to increase the soil $\mathrm{pH}$, improve the soil fertility and increase the crop yield. Wood ash has a liming effect of between 8 to 90 percent of total neutralizing power of lime and can increase plant grows up to $45 \%$ over traditional limestone (Risse, 2013).

Wood ash is easily applied with con-ventional lime or manure spreading equipment. Distribution of ashes is difficult. Therefore, their possible granulation and granular solubility are studied. The effect of granulation and ammonium sulfate addition on the solubility and bioavailability of nutrients and harmful elements from peat and wood co-combustion was investigated (Pesonen and etc. 2017).

Wood ash, in particular, contains all the nutrients that plants need in almost correct proportions, excluding nitrogen, which is released into the atmosphere during combustion. Nitrogen could be added to ash fertilizers by co-granulating bioash, for example, with sewage sludge (Pesonen and etc. 2016). However, co-granulation has not been studied extensively.

The method to produce lightweight aggregates by granulating peat-wood ash using alkali activators is shown (Yliniemi and etc, 2016). The peat-wood ash was granulated with potassium silicate and sodium aluminate in a highshear granulator to produce spherical granules. The study shows that by simultaneous granulation and alkali activation it is possible to increase the utilisation of ash and produce valuable products. The present paper is dedicated to granulation of wood ash using liquid manure.

\section{MATERIALS AND METHODS}

Ash samples for analysis were taken in March 2015 and February 2016 from 2 different heat boilers. For analysis ash that just came from the firebox / ash box / and one month old ashes, which have remained in a landfill in the open sky, were used. The ash which was taken from the ash boxes was produced by the boiler house on the same day.

Table 1. Results of analysis of ash samples.

\begin{tabular}{|c|c|c|c|c|c|c|}
\hline Components & Simbol & Units & Sample No. 1 & Sample No. 2 & Sample No. 3 & Sample No. 4 \\
\hline Antimony & $\mathrm{Sb}$ & $\mathrm{mg} / \mathrm{kg}$ & 1.3 & 1.27 & 1.25 & 1.31 \\
\hline Arsenic & $\mathrm{As}$ & $\mathrm{mg} / \mathrm{kg}$ & 3.4 & 3.2 & 3.1 & 3.3 \\
\hline Barium & $\mathrm{Ba}$ & $\mathrm{mg} / \mathrm{kg}$ & 1800 & 1600 & 1650 & 1670 \\
\hline Zinc & $\mathrm{Zn}$ & $\mathrm{mg} / \mathrm{kg}$ & 737.5 & 1356.1 & 1019.5 & 411.1 \\
\hline Mercury & $\mathrm{Hg}$ & $\mathrm{mg} / \mathrm{kg}$ & 0.03 & 0.03 & 0.025 & 0.027 \\
\hline Phosphorus & $\mathrm{P}$ & $\%$ & 0.7 & 1.14 & 1.21 & 1.07 \\
\hline Chromium & $\mathrm{Cr}$ & $\mathrm{mg} / \mathrm{kg}$ & 25 & 27 & 25 & 26 \\
\hline Cadmium & $\mathrm{Cd}$ & $\mathrm{mg} / \mathrm{kg}$ & 2.3 & 3.2 & 2.9 & 2.4 \\
\hline Calcium & $\mathrm{Ca}$ & $\mathrm{mg} / \mathrm{kg}$ & 130000 & 132000 & 126000 & 128000 \\
\hline Potassium & $\mathrm{K}$ & $\%$ & 2.32 & 3.06 & 2.34 & 1.71 \\
\hline Magnesium & $\mathrm{Mg}$ & $\mathrm{mg} / \mathrm{kg}$ & 22 & 24 & 25 & 30 \\
\hline Manganese & $\mathrm{Mn}$ & $\mathrm{mg} / \mathrm{kg}$ & 8 & 9 & 12 & 14 \\
\hline Molybdenum & $\mathrm{Mo}$ & $\mathrm{mg} / \mathrm{kg}$ & 1.2 & 1.5 & 1.7 & 1.3 \\
\hline Sodium & $\mathrm{N}$ & $\%$ & 0.21 & 0.1 & 0.08 & 0.12 \\
\hline Nickel & $\mathrm{Ni}$ & $\mathrm{mg} / \mathrm{kg}$ & 32 & 27 & 28 & 30 \\
\hline Lead & $\mathrm{Pb}$ & $\mathrm{mg} / \mathrm{kg}$ & 59 & 79 & 65 & 72 \\
\hline Vanadium & $\mathrm{V}$ & $\mathrm{mg} / \mathrm{kg}$ & 29 & 27 & 26 & 28 \\
\hline Copper & $\mathrm{Cu}$ & $\mathrm{mg} / \mathrm{kg}$ & 110 & 90 & 90 & 75 \\
\hline Acidity & $\mathrm{pH}$ & $\mathrm{pH}$ & 12.72 & 10.6 & 12.48 & 11.69 \\
\hline
\end{tabular}


Liquid manure samples were taken from lagoons in 4 different farms. Those farms engaged in milk production and the number of cows they have between 800 and 2500th. The lagoon was mixed and then samples were taken. Four samples were taken each time. Analysis of the chemical composition of ash and liquid manure has been carried out at the Agronomic Analysis Laboratory, Jelgava. The results of the analysis are summarized in Table 1 and Table 2.

The analysis of the ash content showed that they comply with the permissible values of certain components in the natural environment determined by the legislation of the Republic of Latvia.

Table 2. Analyses of the chemical composition of liquid manure in different farms

Table 2. Analyses of the chemical composition of liquid manure in different farms
\begin{tabular}{|c|c|c|c|c|c|c|c|}
\hline \multirow{2}{*}{ Farms } & \multirow{2}{*}{ Dry Matter, (\%) } & \multirow{2}{*}{$\mathrm{pH}$} & $\begin{array}{c}\text { Total N } \\
\mathrm{N}+\mathrm{NH}_{4}-\mathrm{N}\end{array}$ & $\mathrm{NH}-\mathrm{N}$ & $\mathrm{P}_{2} \mathrm{O}_{5}$ & \multirow{2}{*}{$\mathrm{K}_{2} \mathrm{O}$} & \multirow{2}{*}{ Organic } \\
\cline { 4 - 9 } & & & \multicolumn{5}{|c|}{$(\%)$, absolute dry sample } \\
\hline A1 & 7.5 & 6.71 & 8.80 & 1.22 & 1.22 & 3.25 & 73 \\
\hline A2 & 8.6 & 6.96 & 1.94 & 1.71 & 1.22 & 2.68 & 84 \\
\hline A3 & 8.0 & 6.76 & 2.23 & 1.64 & 1.54 & 3.70 & 82 \\
\hline A4 & 8.3 & 7.34 & 8.22 & 1.32 & 1.33 & 3.18 & 76 \\
\hline
\end{tabular}

The ash and liquid manure were mixed in a rotary drum granulator (see below Fig.1)) and granules were dried for six days at room temperature $20 \mathrm{C}^{\circ}$ (see below Fig. 7).

\section{RESULTS}

Why was liquid manure used? When analyzing various combinations the mixture of liquid manure and ash maintained the highest $\mathrm{Ph}$ level, which was taken as the main factor (in Table 3).

Table 3. PH reaction of ash and mixture of ash with other added liquid substances.

\begin{tabular}{|c|c|c|c|c|c|}
\hline No. & Ash from ash boxes & Ash from the landfill & Ash $+\mathrm{H}_{2} \mathrm{O}$ & Ash+HNO 3 & Ash + liquid manure \\
\hline 1. & 11.82 & 10.23 & 6 & 4.2 & 10 \\
\hline 2. & 11.79 & 10.28 & 5.6 & 4.35 & 9.9 \\
\hline 3. & 11.73 & 10.29 & 6.2 & 4.29 & 9.85 \\
\hline 4. & 11.84 & 10.27 & 5.9 & 4.22 & 10.1 \\
\hline
\end{tabular}

As it can be seen in Tab. $3 \mathrm{Ph}$ levels for a mixture of ash + liquid manure do not change significantly, which cannot be said about the other mixtures.

The main purpose of our research was to develop an experimental equipment that could produce ash granules, which would then be easily incorporated into the soil. The equipment scheme is shown in Figure 1.

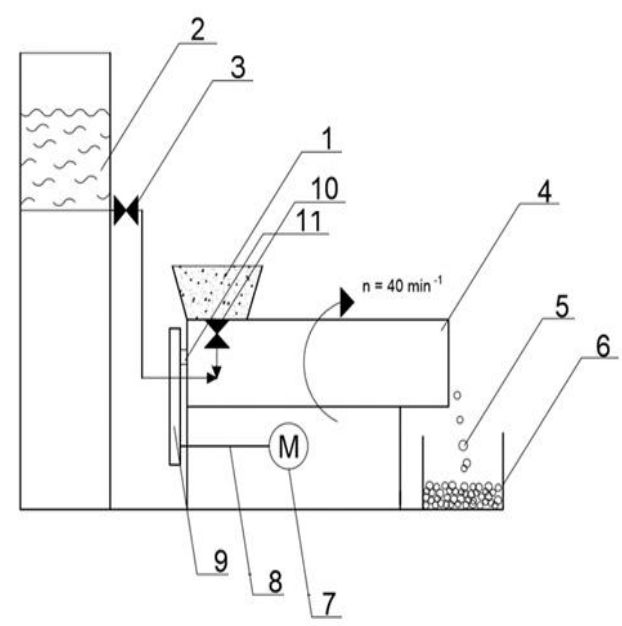

. Ash box;

2. Liquid tank;

3. Liquid tank valve;

4. Rotating drum;

5. Granulas;

6. Tank of granulas;

7. Electric motor;

8. Axle connecting the motor with a coupling belt;

9. V-belt transmission;

10 An ash tank valve;

11. Axle connecting the drum and the coupling belt.

Fig. 1. Operation scheme of the granulation equipment

As it be can seen, the size of the granules resulting from the experiment is not the same. Their variation values (minimum and maximum lengths) are shown in Table 4.

In each mixture, the determining size granule fraction accounted for about $95 \%$ of all granules. Changing the ash - liquid manure ratio various sizes of ash + liquid manure mixture pellets were obtained. The results of the pellet size (average length and width) are shown in Tab.5 and Figures 2-6. 
Table 4. Minimal and maximal sizes of granules obtained in the experiment

\begin{tabular}{|c|c|}
\hline Ratio of ash and liquid manure & Min and max size \\
\hline $1000 \mathrm{ml}$ and $200 \mathrm{ml}$ & $1 \mathrm{~mm}-5 \mathrm{~mm}$ \\
\hline $1000 \mathrm{ml}$ and $300 \mathrm{ml}$ & $1 \mathrm{~mm}-7 \mathrm{~mm}$ \\
\hline $1000 \mathrm{ml}$ and $400 \mathrm{ml}$ & $1 \mathrm{~mm}-12 \mathrm{~mm}$ \\
\hline $1000 \mathrm{ml}$ and $500 \mathrm{ml}$ & $5 \mathrm{~mm}-32 \mathrm{~mm}$ \\
\hline $1000 \mathrm{ml}$ and $600 \mathrm{ml}$ & $10 \mathrm{~mm}-53 \mathrm{~mm}$ \\
\hline
\end{tabular}

Table 5. Dependence of the average length and average width of the pellets on the ash and liquid manure ratio

\begin{tabular}{|c|c|c|c|c|c|}
\hline No. & $\begin{array}{c}\text { Ratio of ash to liquid } \\
\text { manure } \\
\mathrm{ml}\end{array}$ & $\begin{array}{c}\text { Pellets average length } \\
\mathrm{mm}\end{array}$ & $\begin{array}{c}\text { Standart } \\
\text { deviation }\end{array}$ & $\begin{array}{c}\text { Pellets average width } \\
\text { mm }\end{array}$ & $\begin{array}{c}\text { Standart } \\
\text { deviation }\end{array}$ \\
\hline 1. & 1000 and 200 & 1.5 & 0.5 & 2.2 & 0.3 \\
\hline 2. & 1000 and 300 & 4.1 & 0.8 & 4.25 & 0.6 \\
\hline 3. & 1000 and 400 & 6.5 & 2.0 & 5.7 & 1.5 \\
\hline 4. & 1000 and 500 & 13.4 & 5.0 & 12.9 & 4.2 \\
\hline 5. & 1000 and 600 & 36.9 & 4.9 & 39.8 & 4.6 \\
\hline
\end{tabular}

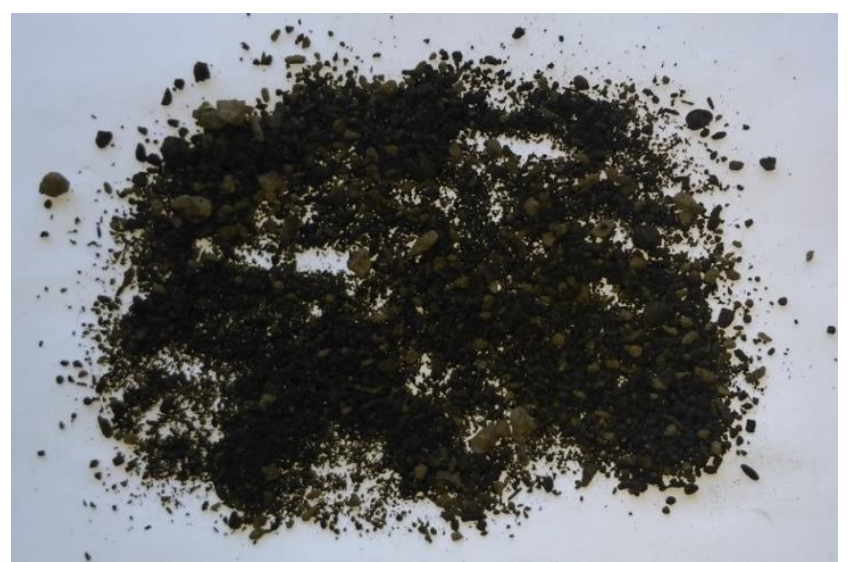

Fig.2. Pellets of mixture $1000 \mathrm{ml}$ ash and $200 \mathrm{ml}$ liquid manure

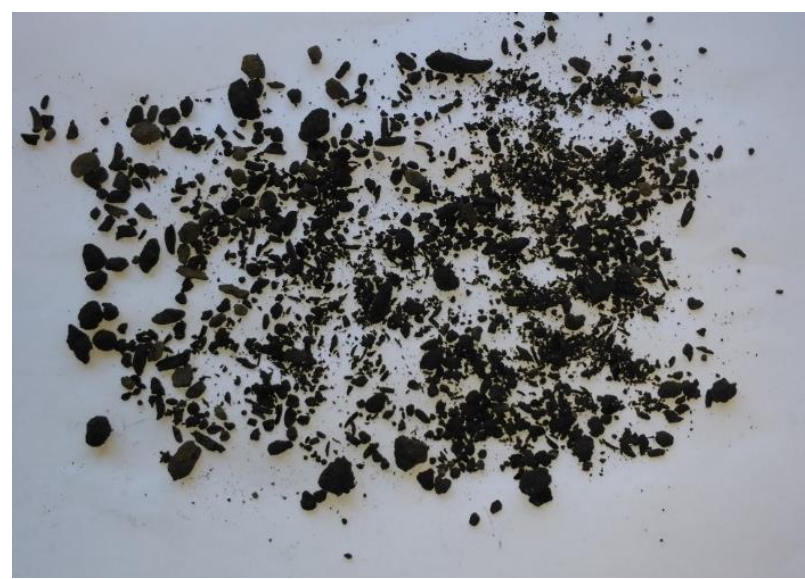

Fig. 4. Pellets of mixture $1000 \mathrm{ml}$ ash and $400 \mathrm{ml}$ liquid manure

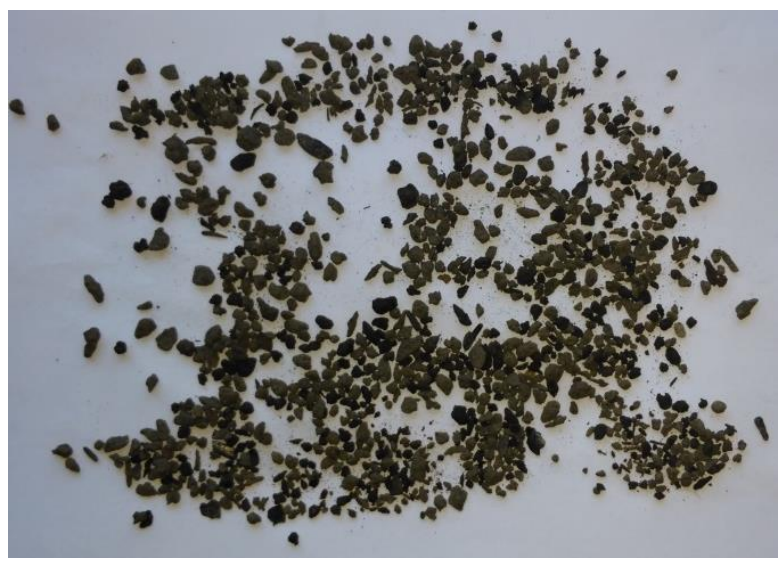

Fig.3. Pellets of mixture $1000 \mathrm{ml}$ ash and $300 \mathrm{ml}$ liquid manure

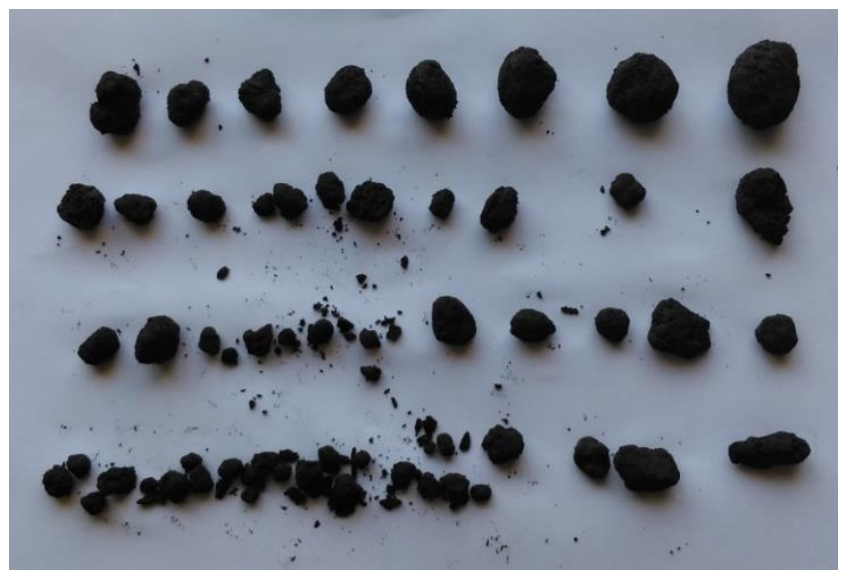

Fig. 5. Pellets of mixture $1000 \mathrm{ml}$ ash and $500 \mathrm{ml}$ liquid

manure

As the experimental results show, the best used ratio of the mixtures was $1000 \mathrm{ml}$ of ash and $200 \mathrm{ml}$ of liquid manure or $1000 \mathrm{ml}$ of ash and $300 \mathrm{ml}$ of liquid manure. In this situation, the received granule sizes were very close to the size of mineral fertilizers (Table 5 and Fig. 2-3). The dimensions coincide with NPK 92525 regulations, where fertilizer grain sizes are below $1 \mathrm{~mm} \mathrm{3 \%}$, from $1 \mathrm{~mm}$ to $6 \mathrm{~mm}, 97 \%$ and not more than $6 \mathrm{~mm}$ (Product specification NPK 9-25-25, 2016). 


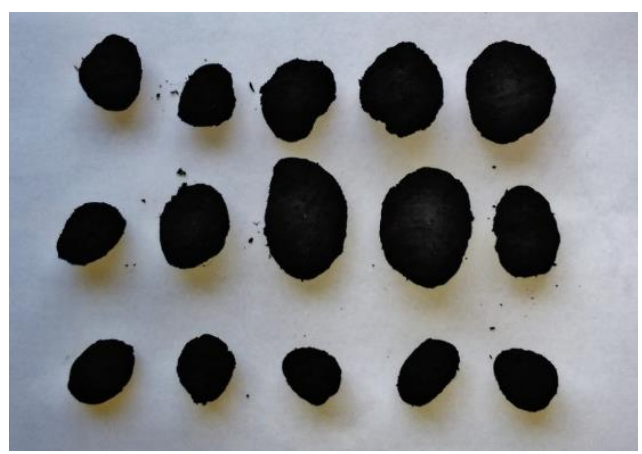

Fig. 6. Pellets of mixture $1000 \mathrm{ml}$ ash and $600 \mathrm{ml}$ liquid manure

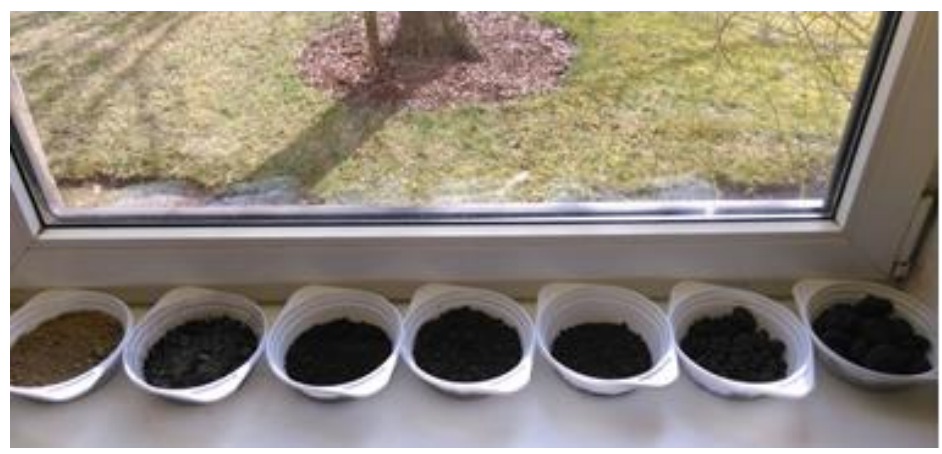

Fig. 7. Pellets drying conditions

Granules of this kind can be easily incorporated into the ground using fertilizer spreaders. It should be noted that the dispersion of this type of ash granules does not smudge dust, which is observed at ash dispersion.

\section{CONCLUSIONS}

1. Biomass ash is suitable for use as a fertilizer in pean lands, which contain high amount of nitrogen, but lack phosphorus and potassium. Necessary nitrogen for plants can be added in the granulation process using liquid manure in the granulation process.

2. Granulated ash is a significiently more cost-effective alternative for ash recycling compared with unprocessed ash. Granulation prevents dust problems during transportation and application. It is possible to get granules of varying sizes using a rotating drum. The granule size depends on the ash and liquid manure ratio.

3. The experimental results showed that the best used ratio of the mixtures was $1000 \mathrm{ml}$ of ash and $200 \mathrm{ml}$ of liquid manure or $1000 \mathrm{ml}$ of ash and $300 \mathrm{ml}$ of liquid manure. In this ratio, the produced granule size was very close to the size of mineral fertilizers and it can be disseminated with fertilizer spreaders.

\section{REFERENCES}

1. Asquer C., Cappai G., De Gioannis G., Muntoni A., Piredda M., Spiga D. 2017. Biomass ash reutilisation as an additive in the composting process of organic fraction of municipal solid waste. Waste Management, Vol. 69, pp. 127-135. https://doi.org/10.1016/j.wasman.2017.08.009

2. Atjaunojamo energoresursu patēriņš pēdējos desmit gados pieauga par 12\% [tiešsaiste].2015. Centrālās statistikas pārvalde, Latvija (Renewable energy consumption in the last ten years increased by $12 \%$ [online] (2015). Central Statistical Bureau, Latvia) [Viewed 2016. g. 23.October]. Available at: http://www.csb.gov.lv/notikumi/atjaunigoenergoresursu-paterins-pedejos-desmit-gadospieauga-par-12-41874.html [In Latvian]

3. Bekeris P. Potenciāli risinājumi pelnu utilizācijā,( Potential solutions in ash utilization) Baltijas koks 02-03 2015, pp. 58-61. [In Latvian]

4. B. Carrasco, B., Cruz, N., Terrados, J., Corpas, F.A., Pérez, L. 2014. An evaluation of bottom ash from plant biomass as a replacement for cement in building blocks. Fuel, Vol. 118, Iss. 15, pp. 272-280.

5. Fernández-Pereira C., Casa J.A.,Gómez-Barea A., Arroyo F., Leiva C., Luna Y. Application of biomass gasification fly ash for brick manufacturing. Fuel, Vol. 90, Iss. 1, pp. 220-232.

6. Garsia M, Sousa-Coutinho J. Strength and durability of cement with forest waste bottom ash Construction and Building Materials Vol. 41, April 2013, pp. 897-910. https://doi.org/10.1016/j.conbuildmat.2012.11.081

7. Kizinievic O., Kizinievic V. 2016. Utilisation of wood ash from biomass for the production of ceramic products. Construction and Building Materials, Vol. 127, Iss. 30, pp. 264-273. https://doi.org/10.1016/j.conbuildmat.2016.09.124

8. Mandre M. 2006. Influence of wood ash on soil chemical composition and biochemical parameters of young Scots pine. Proceedings of the Estonian Academy of Sciences, Biology and Ecology, Vol. 55, No. 2, pp. 91-107.

9. Oburger E., Jager A., Pasch A., Dellantonio A., Stampfer K., Wenzel W. 2016. Environmental impact assessment of wood ash utilization in forest road construction and maintenance - A field study. Science of Total Environment, Vol.544, Feb. pp. 711-721. https://doi.org/10.1016/j.scitotenv.2015.11.123

10. Ots K., Tilk M., Aguraijuja K. 2017. The effect of oil shale ash and mixtures of wood ash and oil shale ash on the above-and belowground biomass formation of Silver birch and Scots pine seedlings on a cutaway peatland. Ecological Engineering, Vol. 108, Part A., pp. 296-306.

11. Pesonen, J., Kuokkanen, V., Kuokkanen, T., Illikainen, M. 2016. Co-granulation of bio-ash with sewage sludge and lime for fertilizer use. Journal of Environmental Chemical Engineering, Vol 4, Iss. 4, pp. $4817-4821$. https://doi.org/10.1016/j.jece.2015.12.035

12. Pesonen, J., Kuokkanen, T., Rautio, P., Lassi, U. 2017. Bioavailability of nutrients and harmful elements in ash fertilizers. Effect of granulation Biomass and Bioenergy, Vol.100, pp. 92-97. https://doi.org/10.1016/j.biombioe.2017.03.019

13. Product specification NPK 9-25-25, Moscow, Russia, 2016. Avaiable: https://phosagro.com/upload/enproduct/9-25-25.pdf 
14. Thurdin T., van Hees P., Bylund D., Lundstrom U. 2006. Bio fuel ash in a road construction:impact on soil solution chemistry. Waste management, Vol. 26, pp. 593-613.

15. Rafat Siddique, 2012. Utilization of wood ash in concrete manufacturing. Resources, conservation and Recycling, Vol. 67, pp. 27-33. https://doi.org/10.1016/j.resconrec.2012.07.004

16. Risse M. 2013. Best management practices for wood ash as agricultural soil amendment. UGA Cooperative Extension bulletin 1142 .

17. Shuiping Y, Qingyao H., Wenhao W., Shefeng L. 2017. $\mathrm{CO}_{2}$ absorption using biogas slurry: absorption enhancement induced by biogas ash. Energy Procedia, Vol. 114, pp. 890-897. https://doi.org/10.1016/j.egypro.2017.03.1232

18. Siddique R. 2012. Utilization of wood ash in concrete manufacturing Resources. Conservation and Recycling, Vol. 67, pp. 27-33. https://doi.org/10.1016/j.resconrec.2012.07.004

19. Yliniemi, J., Nugteren, H., Illikainen, M., Tiainen, M., Weststrate, R., Niinimäki, J. 2006. Lightweight aggregates produced by granulation of peat-wood fly ash with alkali activator. International Journal of Mineral Processing, 149, pp. 42-49. https://doi.org/10.1016/j.minpro.2016.02.006 